DEPARTMENT OF THE INTERIOR UNITED STATES GEOLOGICAL SURVEY

PREPARED IN COOPERATION WITH THE COMMONWEALTH OF MASSACHUSETTS

DEPARTMENT OF PUBLIC WORKS

\title{
AEROMAGNETIC MAP OF THE SOMERSET QUADRANGLE, BRISTOL COUNTY, MASSACHUSETTS
}

\author{
GEOPHYSICAL INVESTIGATIONS \\ MAP GP-792
}

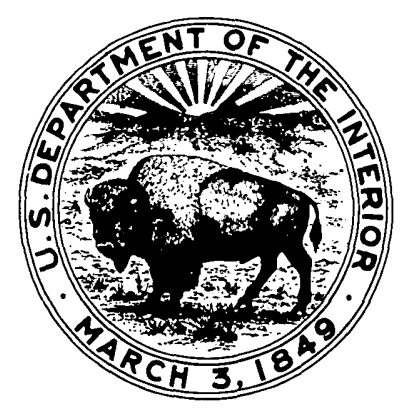

PUBLISHED BY THE U.S. GEOLOGICAL SURVEY WASHINGTON, D.C. 20242 